\title{
Evaluation of Beef Cow Colostrum with a Refractometer
}

\section{DOI:10.3127/air.12588}

Garland Dahlke, Iowa Beef Center, Iowa State University Devin Jakob, Gra duate Student, University of Nebraska

\section{Summary and Implications}

The use of a handheld refractometer measuring percent Brix can be used to provide an estimate of colostrum quality in beef cows a sit does in dairy cows.

\section{Introduction}

The value of colostrum is well documented and mea surements to evaluate the colostrum quality havebeen widely discussed. Most of this work involved dairy cattle due to convenience, but colostrum is equally important in beef ca ttle and a assessment of quality is valuable when there are delays in the cow accepting the calf or when health issues begin to occur a t a higher frequency in new born calves. Although it was expected that dairy cow and beef cow colostrum should have simila r properties, the large difference in the volume of colostrum produced between dairy and beef breeds did motivate an inquiry.

\section{Materials and Methods}

Colostrum samples were collected from 46, September calving, mature, Angus cows at the Iowa State University McNay Research Farm immediately after ca lving to within 18 hours after calving. Samples were split in to two samples and froze. After the la st sample was collected one set of the sa mples was sent to the Cornell University Animal Health and Diagnostic Center which reported the concentration of Immunoglobin $\mathrm{G}(\mathrm{IgG})$, true protein concentration and milk urea nitrogen in each sample. The matching set of samples, which was retained, was allowed to tha w and wa rm to room temperature (approximately 22 degrees Celsius). Each sample was then mixed and oneml was taken from the sample and placed on the lens of the VEE GEE BTX-1 hand held, optical refractometer (Figure 1) to observe the percent Brix. The percent Brix and the IgG concentration were then paired and evaluated.

\section{Results and Discussion}

Table 1 provides a summary of what was measured and Table 2 provides the correlations between these measures. Figure 2 illustrates the rela tionship observed between IgG and percent Brix. It did a ppear that the rela tionship wa not linear and followed the polynomial equation shown in Figure 2. The refractometer used was calibrated to 35 percent Brix and this may have been a factor into why we observed the polynomial relationship between percent Brix and IgG concentrations rather than linear a s others have reported since there were at least four samples that were greater than $35 \%$ Brix.

There was a strong positive correlation between the percent Brix and the IgG concentration (0.80) as others have mentioned from past research thus confirming what we have found. The Cornell lab mentions in their report that the reference interval for IgG in a dult cattle is 1700-2700 $\mathrm{mg} / \mathrm{dL}$. The expected value for $\mathrm{IgG}$ in calves receiving a dequate colostrum is $1200 \mathrm{mg} / \mathrm{dL}$ or greater. Values from a J. of Da iry Science paper $(93: 3713)$ indicate that concentrations from 20 to $100+\mathrm{g} / \mathrm{L}$ a re common and that high-quality colostrum will be $50 \mathrm{~g}$ of $\mathrm{IgG} / \mathrm{L}$ or better. The IgG values we received were in this range with most being a bove $50 \mathrm{~g}$ of $\mathrm{IgG} / \mathrm{L}$. There were a number of low concentrations that were a function of delayed sampling however.

If $50 \mathrm{~g}$ of $\mathrm{IgG} / \mathrm{L}(5000 \mathrm{mg} / \mathrm{dl})$ is a dequate, this would correspond with a value of $16 \%$ Brix with the data presented here. This is a significantly lower percent Brix than what the J. of Dairy Science article would indicate where they sta te that a reading of $22 \%$ Brix corresponded to the IgG level of $5000 \mathrm{mg} / \mathrm{dl}$.

The la $\mathrm{b}$ also provided milk urea nitrogen (MUN) and total protein for ea ch sample a s well. Total protein and IgG concentrations were strongly correlated (0.89) as might be expected, but it was interesting that there was a mild negativecorrelation between percent Brix and $\operatorname{MUN}(-0.24)$.

\section{Acknowledgements}

The authors would like to thank the staff of the ISU McNay Research Farm for their a ssistance with this project.

Copyright (C) 2021 by the Authors. This is an open a ccess article published under the CC BY-NC license (https://creativecommons.org/licenses/by-nc/4.0/), which allows for non-commercial reuse with proper a ttribution. 
Figure 1.VEE GEE BTX-1 ha ndheld refractometer.

Table 1. Summary of colostrum.

\begin{tabular}{|l|l|l|l|l|}
\hline & \% Brix & IgG mg/dl & $\begin{array}{l}\text { True Milk Protein } \\
\text { g/dl }\end{array}$ & $\begin{array}{l}\text { Milk Urea } \\
\text { Nitrogen mg/dl }\end{array}$ \\
\hline Average & 21.5 & 6593 & 14.7 & 13.6 \\
\hline St. Deviation & 7.8 & 2348 & 6.2 & 3.5 \\
\hline Minimum & 10 & 619 & 3.2 & 9 \\
\hline Maximum & 36 & 9628 & 27.3 & 23 \\
\hline
\end{tabular}

Table 2. Correla tions between colostrum results.

\begin{tabular}{|l|l|l|l|}
\hline & Total Protein & IgG & Milk Urea Nitrogen \\
\hline \% Brix & 0.72 & 0.80 & -0.29 \\
\hline Total Protein & & 0.89 & -0.24 \\
\hline
\end{tabular}

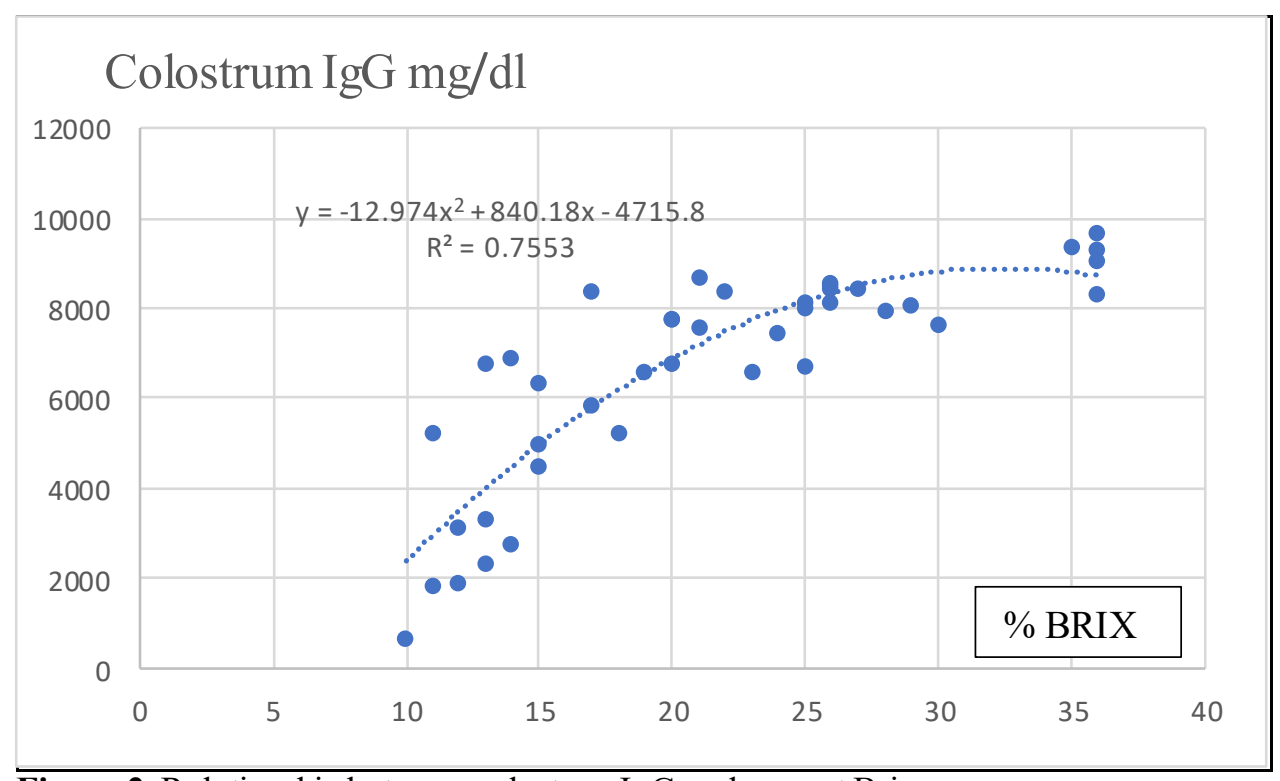

Figure 2. Rela tionship between colostrum IgG and percent Brix. 